\title{
INFLUENCE OF ANAESTHETIC DRUGS ON AMINO ACID INCORPORATION IN THE RAT PANCREAS
}

\author{
M. F. Kramer and C. Poort \\ Department of Histology and Cell Biology, School of Medicine, University of Utrecht, \\ The Netherlands
}

(Received 13 July 1971; accepted 3 September 1971)

\begin{abstract}
Barbiturates, nitrous oxide and ethylurethane do not affect the rate of protein synthesis in the exocrine cells of the rat pancreas in vivo during the first 15 min of anaesthesia. Ethylether and trichloroethylene decrease the rate of incorporation of radioactive amino acid ( $l$-leucine) into protein by more than $\mathbf{4 0}$ and 30 per cent respectively. They also inhibit the incorporation of radioactive amino acid into slices of pancreas in vitro, the inhibition increasing (up to 100 per cent) with increasing amount of anaesthetic in the gassing mixture. Therefore, the influence of these lipid solving anaesthetics on the cells in vivo can be seen as mainly a direct one, not mediated by the lower body temperature or hypoxaemia. The inhibition of the leucine incorporation is reversible with low concentrations of ether, as are present in the blood during inhalation anaesthesia. Since the inflow of radioactive leucine into the tissue is not inhibited by ether, a lower specific radioactivity of free leucine in the cells is not the main cause of the decrease in incorporation.
\end{abstract}

ANAESTHESIA was needed in some of our experiments on the rate of protein synthesis in the exocrine pancreas at different states of secretion. We therefore tested a number of anaesthetics for their influence on incorporation of radioactive amino acid into pancreatic protein. Experiments were performed in vivo and in vitro.

\section{METHODS AND MATERIALS}

In the first series of experiments 33 female albino rats (Fa. "Albino", Oss, the Netherlands) at a weight of 133-198 $\mathrm{g}$ have been used; the other series of experiments were done on 43 Wistar rats (Centraal Proefdierenbedrijf TNO, Zeist, the Netherlands) at a weight of 163-208 g. All animals were starved for $24 \mathrm{hr}$ before anaesthesia, except four rats of the first series that were fed $a d$ lib. after a 24 -hr period of starvation and anaesthesized $5 \mathrm{hr}$ thereafter.

The in vitro experiments were performed on pancreatic tissue from Wistar rats (Centraal Proefdierenbedrijf) at a weight of $190-215 \mathrm{~g}$, starved $24 \mathrm{hr}$ prior to death.

In vivo experiments

Anaesthetic procedures and the anaesthetics used are summarized in Table 1. Anaesthesia was considered to be complete when the animals had lost their righting reflexes and did not react to pin-pricks. Then rectal temperature was measured.

L-Leucine-4,5- ${ }^{3} \mathrm{H}$ (1 c/m-mole; $1 \mathrm{mc} / \mathrm{ml}$; The Radio-Chemical Centre, Amersham, G.B.) was injected into a tail vein, at a dose of $1 \mu \mathrm{c} / \mathrm{g}$, a few minutes after complete 
TABle 1. ANaesthetics USED, their dosage and ways of application

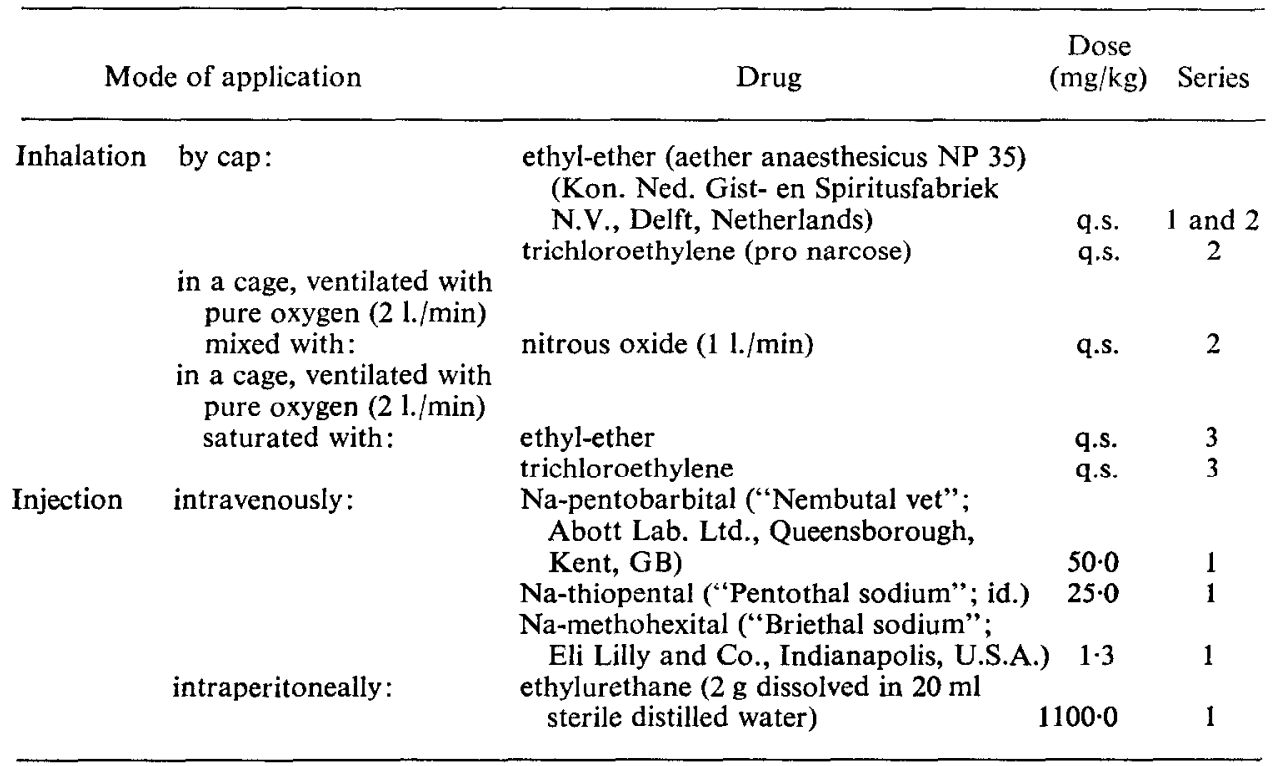

anaesthesia had been attained. The rats were killed by decapitation 10 min after this injection.

The incorporation of leucine- ${ }^{3} \mathrm{H}$ per cell was determined by counting the number of autoradiographic grains per "mean cellular area" in Kodak AR 10-stripping film autoradiographs of $5 \mu$ thick paraffin sections of formaldehyde fixed pancreas, as described earlier. ${ }^{8}$

For the biochemical determination of the incorporation in vivo we prepared a fatfree, TCA insoluble fraction of a part of the excised pancreas. The radioactivity in this fraction was measured in a liquid scintillation counter and expressed as counts/minute per microgram DNA, the DNA being determined with the diphenylamine method. ${ }^{3}$ In this way the incorporation is expressed on a per cell base, as in the case of the autoradiographic data. ${ }^{8}$

\section{In vitro experiments}

The animals were killed by decapitation and the pancreas was quickly removed. Slices of pancreas were incubated for $10 \mathrm{~min}$ at $37^{\circ}$ in $2 \mathrm{ml}$ of improved Ringer III medium, ${ }^{9}$ containing all amino acids in a concentration of $10^{-4} \mathrm{M}$, and $0.5 \mu \mathrm{c}$ L-leucine-1 $-{ }^{14} \mathrm{C}$ (U) $(331 \mathrm{mc} / \mathrm{m}$-mole; The Radiochemical Centre) per ml. The incubation flasks were gassed with a mixture of $\mathrm{O}_{2}$ and $\mathrm{CO}_{2}$ ( 95 and 5 per cent respectively) at a rate of $160 \mathrm{ml} / \mathrm{min}$.

Part of the in vitro experiments was devoted to the measurement of the rate of leucine- ${ }^{14} \mathrm{C}$ incorporation in pancreatic slices from animals, anaesthesized in vivo, about 5 min prior to death.

Other experiments were performed in order to determine the effect of ether and trichloroethylene in vitro on slices of pancreas of normal, unanaesthesized rats. The gas mixture was led then through a bottle with liquid ether or trichloroethylene, to be 
mixed with these drugs prior to ventilating the incubation flasks. The gas flow ventilating the incubation flasks was 10,20 or 100 per cent saturated with the drug by mixing it with pure $\mathrm{O}_{2} / \mathrm{CO}_{2}$ gas in different proportions (Table 3).* Part of the slices of the same pancreas was gassed with the $\mathrm{O}_{2} / \mathrm{CO}_{2}$ mixture only, as a control.

A third series of experiments was done to determine the reversibility of the ether effect in vitro. The gas mixture with ether was led through the incubation flasks for $5 \mathrm{~min}$. Then the tissue was gassed with the $\mathrm{O}_{2} / \mathrm{CO}_{2}$ mixture without ether, at the same rate. After $8 \mathrm{~min}$ the radioactive leucine was added and the incubation prolonged for a final $10 \mathrm{~min}$. For control, part of the slices of the same gland was gassed with ether, another part with $\mathrm{O}_{2} / \mathrm{CO}_{2}$ only, both for $13 \mathrm{~min}$, radioactive leucine being present in the medium during the last 10 min.

At the end of the incubation period the slices were washed with the incubation medium containing $1 \mathrm{mg}$ of unlabelled leucine per $\mathrm{ml}$. The slices were homogenized in physiological saline and in aliquots of this homogenate DNA was determined, in other aliquots the amount of TCA soluble and of TCA insoluble radioactivity. The amount of TCA soluble radioactivity per $\mu \mathrm{g}$ DNA is used as a measure of the amount of free radioactive leucine being present in the tissue per cell; the amount of insoluble radioactivity is used as a measure of the amount of radioactive leucine incorporated into protein per cell.

\section{Statistics}

All means are mentioned with their standard errors. Differences between means are only considered to be significant, when a $t$-test ${ }^{14}$ yielded a value of $\mathrm{P}<0.05$.

\section{RESULTS}

The incorporation of leucine- ${ }^{3} \mathrm{H}$ per cell, as measured by autoradiography in animals anaesthesized by pentobarbital, thiopental, methohexital, ethylurethane or nitrous oxyde is not significantly different from that of control rats. Anaesthesia by ether or trichloroethylene on the other hand significantly decreased the incorporation of leucine- ${ }^{3} \mathrm{H}$. A lowering of $c a .48$ and 30 per cent respectively was found (Table 2).

These results agreed with the biochemical determinations which, too, showed a significant decrease-by 36 and 34 per cent respectively —of the leucine- ${ }^{3} \mathrm{H}$ incorporation in the case of ether or trichloroethylene anaesthesia (Table 2).

In order to rule out the possibility of hypoxaemia causing the decrease in incorporation rate during ether or trichloroethylene anaesthesia by means of a cap, ${ }^{7}$ an additional experiment was carried out. In this experiment the anaesthetics were administered by the way of ventilation of the animal cage with pure oxygen saturated with ether or trichloroethylene. The effect on the amino acid incorporation into protein was similar to that in the previous series (Table 2).

The lowering of the body temperature accompanying anaesthesia cannot be held responsible for the decreased incorporation after ether or trichloroethylene, since the other anaesthetics cause a similar rapid fall in body temperature within 2 min after complete anaesthesia had been attained (Table 2).

The effect of ether is similar in starved and in fed animals. In the latter a lowering of the incorporation rate by 43 per cent was found.

* The percentages of saturation are mentioned for room temperature $\left(21^{\circ}\right)$. Since the temperature of incubation was $37^{\circ}$, the percentage of saturation in the incubation flasks is in all cases only 55 per cent of the value mentioned. 
TABle 2. INFLueNCE OF ANAESTHETIC DRUGS ON THE INCORPORATION OF LeUCINE- ${ }^{3} \mathrm{H}$ PER CELl IN THE RAT PANCREAS in vivo

\begin{tabular}{|c|c|c|c|c|c|}
\hline \multirow[b]{2}{*}{$\begin{array}{c}\text { Series } \\
\text { no. }\end{array}$} & \multirow[b]{2}{*}{$\begin{array}{l}\text { Body } \\
\text { temp. }\end{array}$} & \multicolumn{2}{|c|}{$\begin{array}{l}\text { Number of autoradio- } \\
\text { graphic grains per } \\
\text { mean cellular area }\end{array}$} & \multicolumn{2}{|c|}{$\begin{array}{c}\text { Counts/min in protein } \\
\text { per } \mu \mathrm{g} \text { DNA }\end{array}$} \\
\hline & & $\begin{array}{l}\text { Mean } \pm \\
\text { S.E.M. }\end{array}$ & $\begin{array}{l}\text { Number of } \\
\text { animals }\end{array}$ & $\begin{array}{c}\text { Mean } \pm \\
\text { S.E.M. }\end{array}$ & $\begin{array}{l}\text { Number of } \\
\text { animals }\end{array}$ \\
\hline
\end{tabular}

\begin{tabular}{|c|c|c|c|c|c|c|}
\hline \multicolumn{7}{|l|}{ Inhalation } \\
\hline Control & $1,2,3$ & $38 \cdot 2-38 \cdot 6$ & $9 \cdot 5 \pm 0.4$ & 19 & $560 \pm 58$ & 13 \\
\hline ether cap & 1,2 & & $4.9 \pm 0.4^{*}$ & 16 & $358 \pm 54 \dagger$ & 11 \\
\hline $\begin{array}{l}\text { ether } 100 \% \mathrm{O}_{2} \\
\text { trichloroethylene cap }\end{array}$ & & $\begin{array}{l}34 \cdot 6-35 \cdot 8 \\
34 \cdot 5-35 \cdot 8\end{array}$ & $\begin{array}{l}5 \cdot 0 \pm 1 \cdot 5^{*} \\
6 \cdot 6+0.8^{*}\end{array}$ & $\begin{array}{l}3 \\
6\end{array}$ & $370+24^{*}$ & 3 \\
\hline $\begin{array}{l}\text { trichloroethylene cap } \\
\text { trichloroethylene }\end{array}$ & & & & & ד & 3 \\
\hline $100 \% \mathrm{O}_{2}$ & 3 & $35 \cdot 5-36 \cdot 2$ & $5.7 \pm 1.4 \dagger$ & 3 & & \\
\hline nitrous oxide $69 \% \mathrm{O}_{2}$ & 2 & $35 \cdot 0-36 \cdot 8$ & $9 \cdot 1 \pm 0 \cdot 8$ & 7 & $493 \pm 85$ & 3 \\
\hline \multicolumn{7}{|l|}{ Injection } \\
\hline Control & 1 & $38 \cdot 2-38 \cdot 5$ & $8.7 \pm 0.7$ & 8 & $558 \pm$ & 8 \\
\hline pentobarbital (iv) & 1 & $34 \cdot 5-35 \cdot 8$ & $8.1 \pm 0.8$ & 5 & $487 \pm 103$ & 5 \\
\hline thiopental (iv) & 1 & $34 \cdot 9-36 \cdot 0$ & $8 \cdot 9 \pm 1 \cdot 1$ & 3 & & \\
\hline methohexital (iv) & 1 & $34 \cdot 5-36 \cdot 3$ & $8 \cdot 0 \pm 0.9$ & 3 & & \\
\hline ethylurethane (ip) & 1 & $36 \cdot 0-37 \cdot 0$ & $8 \cdot 0 \pm 1 \cdot 3$ & 3 & & \\
\hline
\end{tabular}

* Difference with controls: $P<0.01$.

$\dagger$ Difference with controls: $P<0.02$.

In the in vitro experiments leucine- ${ }^{14} \mathrm{C}$ is incorporated in slices of pancreatic tissue. We found no significant differences in the rate of incorporation per cell in slices from control rats and from rats being under ether anaesthesia at the moment of death. However, saturation of the gas mixture over the incubation medium with ether or trichloroethylene decreased the rate of incorporation into TCA insoluble material in pancreas slices from non-anaesthesized rats by practically 100 per cent. In this case, however, the calculated ether concentration in the incubation medium was about 10 times higher than in the blood $(100 \mathrm{mg} / 100 \mathrm{ml})^{5}$ during operation anaesthesia by ether inhalation. The measure of the inhibition was shown to be dependent on the ether content of the gas mixture, and the inhibition was found to be, at least partially, reversible, the degree of recovery being inversely related to the degree of inhibition. No differences could be found in the amount of TCA soluble radioactivity between slices from control experiments and from experiments with ether application (Table 3).

\section{DISCUSSION}

The decreased incorporation of leucine $-{ }^{3} \mathrm{H}$ into protein by the cells of the exocrine pancreas in rats under ether or trichloroethylene anaesthesia is considerable, more than 40 and 30 per cent respectively. The barbiturates, urethane and nitrous oxide do not have such an influence (Table 2).

Hypoxaemia or lowered body temperature are excluded as causes of the effect of ether and trichloroethylene by the results of the in vivo experiments, shown in Table 2 . Since both anaesthetics decrease the amount of leucine- ${ }^{14} \mathrm{C}$ incorporated in vitro too 
TABLE 3. INFLUENCE OF ANAESTHETIC DRUGS ON THE INCORPORATION OF LEUCINE- ${ }^{14} \mathrm{C}$ IN THE CELLS OF THE RAT PANCREAS in vitro

\begin{tabular}{|c|c|c|c|c|}
\hline \multirow[b]{3}{*}{$\begin{array}{l}\text { Atmosphere } \\
95 \% \mathrm{O}_{2}, 5 \% \mathrm{CO}_{2} 160 \mathrm{ml} / \mathrm{min}\end{array}$} & \multicolumn{4}{|c|}{ Radioactivity* per $\mu \mathrm{g}$ DNA } \\
\hline & \multicolumn{3}{|c|}{$\begin{array}{l}\text { TCA insoluble } \\
\text { (expressed as percentage of conłrol) }\end{array}$} & $\begin{array}{l}\text { TCA soluble } \\
\text { (dis./min } / \mu \mathrm{g} \\
\text { DNA) }\end{array}$ \\
\hline & $\begin{array}{l}13 \text { min with } \\
\text { anaesthetic }\end{array}$ & $\begin{array}{l}5 \text { min with, } \\
\text { followed by } \\
18 \text { min without } \\
\text { anacsthetic }\end{array}$ & recovery & $\begin{array}{l}13 \text { min with } \\
\text { anaesthetic }\end{array}$ \\
\hline $\begin{array}{l}\text { Control }(13 \mathrm{~min} \text { without } \\
\text { anaesthetics) } \\
\text { Trichloroethylene } 100 \% \text { sat. }\end{array}$ & $\begin{array}{l}100 \$ \\
0.5( \pm 0.2)\end{array}$ & & & $467( \pm 69)$ \\
\hline $\begin{array}{ll}\text { Ethylether } & 100 \% \text { sat. } \\
& 20 \% \text { sat. } \| \\
& 10 \% \text { sat. } \$\end{array}$ & $\begin{array}{l}0.5( \pm 0.1) \\
38.0( \pm 5 \cdot 7) \\
87.59\end{array}$ & $\begin{array}{r}2.4( \pm 0.1) \\
53.0( \pm 6.9)\end{array}$ & $15( \pm 3)$ & $\begin{array}{l}730( \pm 55) \\
435( \pm 35)\end{array}$ \\
\hline
\end{tabular}

* Radioactive leucine incorporated during the last $10 \mathrm{~min}$ of incubation. (Mean \pm S.E.M.)

† Recovery of incorporative capacity during $8 \mathrm{~min}$ after the end of ether application. (Mean difference $\pm S$. E. of the difference.)

¥ The TCA insoluble radioactivity in the control slices amounts to $513 \mathrm{dis} / \mathrm{min} / \mathrm{\mu g}$ DNA.

$\$$ The gasflow was composed from 4 parts of pure $\mathrm{O}_{2} / \mathrm{CO}_{2}$ and 1 part of $\mathrm{O}_{3} / \mathrm{CO}_{2}$ saturated with ethylether.

II The gasflow was composed from 9 parts of pure $\mathrm{O}_{2} / \mathrm{CO}_{2}$ and 1 part of $\mathrm{O}_{2} / \mathrm{CO}_{2}$ saturated with ethylether.

If Mcan value of two experiments.

(Table 3), changes in blood pressure and composition also can be ruled out as the principal causes of their effect.

The action of ether is reversible, since in vitro pancreatic slices from rats anaesthesized by ether in vivo show the same rate of incorporation as do slices from unanaesthesized control rats. Apparently the tissue gives off the volatile drug rapidly when handled prior to incubation. The effect of ether when applied in vitro appeared to be reversible too, if only the concentration of ether in the gas mixture was not too high (Table 3).

The decreased incorporation in vivo and in vitro could be ascribed to a lower rate of protein synthesis if in the case of ether application the specific radioactivity (s.r.) of the precursor leucine pool does not vary too much from normal values. We have found ${ }^{16}$ that the intracellular store of leucine is not used by the pancreatic cell in the process of protein synthesis in vitro, confirming the results, e.g. obtained by Hider, Fern and London $^{6}$ on muscle tissue. What is used is the extracellular amino acid. This meansthe s.r. of the extraccllular precursor pool being constant-that in vitro in the presence of ether the lower rate of incorporation reflects a lower rate of protein synthesis.

If, notwithstanding our evidence to the contrary, the intracellular amino acid is used, a conclusion on the rate of protein synthesis may only be drawn if the s.r. of the intracellular leucine is unaffected by ether. The net inflow of radioactive leucine into the tissue after $10 \mathrm{~min}$ is unaffected by ether in vitro, while its incorporation is decreased with 60 per cent or more (Table 3). This implies that the decrease in incorporation of radioactive leucine does not result from a drastically lowered s.r. of the 
intracellular leucine, for a decrease of the s.r. of an amino acid by 60 per cent (let alone by 99 per cent) is very improbable, when it flows into the cell at a normal rate (the intracellular pool should be less than half its normal size in the case of ether intoxication, at a normal rate of net inflow!).

So we feel our conclusion-- the decrease in rate of incorporation of radioactive leucine does not result from a lower s.r. of the leucine--being justified irrespective of the amino acid being activated for protein synthesis out of the extra- or out of the intra-cellular pool.

On the other hand our data do not allow a choice between other possible explanations of the decreased incorporation: ether might affect amino acid activation or the coupling to transfer RNA; it might impede the process of protein synthesis itself; it finally could decrease the formation of substances like ATP in mitochondria. Since ether and trichloroethylene are potent lipid solvents, in contrast to the other drugs investigated, it is tempting to see cellular membranes as their possible site of action,* making the involvement of mitochondria more probable.

The normal leucine incorporation after administration of the other drugs can safely be interpreted as an indication of an unchanged rate of protein synthesis in the pancreas of rats during the first $15 \mathrm{~min}$ of anaesthesia by barbiturates, urethane or nitrous oxide.

In contrast to our results $\operatorname{Rapp}^{12}$ reported an inhibitory effect of an anaesthetic dose of pentobarbital on amylase synthesis in the rat parotid gland, while Baserga and Weiss ${ }^{1}$ observed a decrease in incorporation of radioactive leucine in Ehrlich ascites cells in mice, treated with $50 \mathrm{mg} / \mathrm{kg}$ pentobarbital intravenously. Kröner and Staib ${ }^{10}$ described a 40 per cent lower incorporation of radioactive leucine in liver protein in rats during the first hour of barbital $(150 \mathrm{mg} / \mathrm{kg}$, intraperitoneally) anaesthesia. The decrease was not caused by the lower body temperature and was reversed into an incorporation higher than normal after $3 \mathrm{hr}$.

Our results with ether, however, find their parallel in the reported decreasing effect on amylase synthesis in the rat parotid gland. ${ }^{12}$ Chloroform is reported to diminish the leucine incorporation in the centre of the rat liver lobules, while halothane had no influence. ${ }^{13}$

The described influence of anaesthetics on the rate of amino acid incorporation and protein synthesis must be well discerned from their reported influence on pancreatic secretion. ${ }^{2,4,11,15}$

Acknowledgements-Thanks are due to Prof. Dr. M. T. Jansen for his critical review of the manuscript. We thank Miss A. C. Korteweg and Mr. J. G. van Essen for skilful technical assistance and Mr. R. Dol for carrying out the anaesthetic procedures.

\section{REFERENCES}

1. R. BASERGA and L. WeISS, Biochim. biophys. Acta 145, 361 (1967).

2. G. Ben Ari, J. Rudick, A. E. Kark and D. A. Dreiling, The Physiologist 10, 123 (1967).

3. K. BURTON, Biochem. J. 62, 315 (1956).

4. R. J. Coffey, Th. Koppanyi and Ch. R. Linegar, Am. J. dig. Dis. 7, 21 (1940).

5. F. T. Evans and T. C. Gray, General Anaesthesia (2nd ed.), Vol. I, p. 411. Butterworths, London (1965).

6. R. C. Hider, E. B. Fern and D. R. London, Biochem. J. 121, 817 (1971).

* Tissue slices stuck strongly to the wall of the incubation flasks, when aerated with the gas mixture maximally saturated with ether, demonstrating a change in surface activity of tissue components. 
7. R. L. Katz, S. H. Ngai, D. C. Brody and E. M. PAPPer, Acta Anaesth. Scand., Suppl. 12, 40 (1962).

8. M. F. Kramer and C. Poort, Z. Zellforsch. 86, 475 (1968).

9. H. A. KREBS, Biochim. biophys. Acta 4, 249 (1950).

10. H. KRÖNER and W. STAIB, Z. Klin. Chem. u. Klin. Biochem. 8, 41 (1970).

11. T. M. Liv and R. S. Alphin, Am. J. Physiol. 203, 926 (1962).

12. G. W. RaPp, J. Dent. Res. 40, 1225 (1961).

13. K. L. Scholler, E. Müller and U. v. Plehwe, Der Anaesthesist 17, 87 (1968).

14. G. W. SNEDECOR, Statistical Methods (4th ed.), section 4.5, The Iowa State College Press, Ames (1946).

15. W. Thorn, F. Liemann, R. Hirsch and K. Straub, Arzneimittel-Forsch. 17, 1469 (1967).

16. W. J. van Venroou, M. F. KRamer, C. Poort and M. T. JANSEN, to be published. 